\title{
An Empirical Investigation of Knowledge Management Strategy and Information Technology Strategy on Performance
}

\author{
Chih-Hsiung Chang ${ }^{1} \&$ Yang-Ching Yen ${ }^{2}$ \\ ${ }^{1}$ Department of Finance, I-Shou University, Kaohsiung, Taiwan, R.O.C. \\ ${ }^{2}$ Department of Finance and Center for General Education, I-Shou University, Kaohsiung, Taiwan, R.O.C. \\ Correspondence: Yang-Ching Yen, Department of Finance and Center for General Education, I-Shou University, \\ Kaohsiung, Taiwan, R.O.C. Tel: 886-93-974-6179. E-mail: yyc0103@isu.edu.tw
}

\author{
Received: March 4, 2019 Accepted: March 19, $2019 \quad$ Online Published: April 30, 2019 \\ doi:10.5539/ass.v15n5p44 URL: https://doi.org/10.5539/ass.v15n5p44
}

\begin{abstract}
Recently, a great number of theoretical frameworks have been proposed to develop the linkages between knowledge management (KM) and organizational strategy. While there has been much theorizing and case study in the area, validated research models integrating KM strategy and information technology (IT) strategy for empirical testing of these theories have been scarce.

It is thought that the rapid progress of IT has been provided a good solution to support KM practices. Choosing the proper ITs to fit with different KM strategies is critical for organizations. Effective KM activities require employing KM strategies, as well as IT, appropriately. That is, as long as the KM strategy has been determined within an organization, the IT strategy must be followed. In this present research, we try to develop and examine a research model for explaining the relationships between KM strategy, IT strategy, and their effects on performance. Empirical data for hypotheses testing are collected from top-ranked companies in Taiwan; yielding 161 valid samples. The findings showed that KM strategy has a positive direct effect upon IT strategy; KM strategy and IT strategy have significant positive effects upon KM performance and IT performance respectively, and then collectively, have the impact upon business performance. Finally, from the empirical data analysis, meaningful findings and conclusions are derived, and suggestions for future research are proposed and discussed.
\end{abstract}

Keywords: knowledge management strategy, information technology strategy, knowledge management performance, information technology performance

\section{Introduction}

In the unpredictable and turbulent business operational environment, firms are facing severe challenges in the global environment. Thus, it is critical for a business to acquire various kinds of skills and capabilities that are valuable, rare, and difficult to imitate or substitute (Barney, 1986; 1991). According to this, the integration of firm's various kinds of resources that are costly-to-copy is seen as the vital work for business to achieve higher operations performance (Barney, 1991; Conner, 1991; Schulze, 1992).

Now, knowledge has been considered as an important resource than other physical assets (e.g., land, capital and machines) (Drucker, 1993) which enables organizations to achieve faster learning and develop better decision-making processes. In this complicating and rapidly changing business environment, therefore, Knowledge management $(\mathrm{KM})$ is the organizational strategic practices and critical strategy to achieve sustainable competitive advantage (Alavi \& Leidner, 1999; Davenport \& Prusak, 1998; Grant, 1996; Johannessen \& Olsen, 2003; Zack, 1999a) because KM strategy is an overall change process that focused on innovation, through its creation, transmission, and application (Cohen \& Levinthal, 1990; Marques et al., 2017).

Nowadays, the critical roles of information technology (IT) and information system (IS) in supporting KM practices have also been indicated and examined (e.g., Alavi \& Leidner, 2001; Choi \& Lee, 2002; Kankanhalli et al., 2003; Nonaka \& Konno, 1998; Tiwana, 2012; Zack, 1999b). Thus, many firms have spent a vast amount of IT/IS resources in order to improve their KM performance because IT/IS has its ability to support connection, collaboration, communication, and form virtual knowledge communities in helping staff's learning (Alavi et al., 1997; Kim, 2001). As Ruggles (1998) argued, creating an intranet, data warehousing, knowledge repositories, 
expert maps, decision-support tools, groupware are ways to support KM. Additionally, many enterprises start using modern IT/IS (e.g., artificial intelligence systems, office automation systems, knowledge management systems...etc.) to support capturing, storing, retrieving, and distributing of their explicitly documented knowledge (Zack, 1999a). Other tools including e-mail system, on-line discussion networks, videoconferencing...etc. which provided by IT for KM, involves helping to connect experts in the organization (Scheepers et al., 2004).

From the foregoing discussions, at least two research themes may increase knowledge in this area. First, one can examine the alignment effects between IT design and KM (e.g., Baloh, 2007; Chen et al., 2012; Chen \& Huang, 2012). Its underlying notion is that owing to the complexity of KM initiatives and the various kinds of IT techniques developed, businesses must pay more attention to implementing IT infrastructure to support their KM initiatives (Dulipovici \& Robey, 2013; Kankanhalli et al., 2003). Thus, the matching mechanism of IT and KM is an important concern for firms. Second, developing a better understanding of the cause-and-effect between IT use and KM.

Therefore, this study focused on providing empirical evidence of the relationship between knowledge management (KM) strategy and information technology (IT) strategy. We posit that performance variables including business performance, KM performance, and IT performance are affected by these two strategies respectively. This paper is organized as follows. First, the concept of KM strategy and IT strategy will be discussed, following by the hypotheses development and conceptual research model. The development of research measurement items and data collecting methods then will be outlined. This will be followed by data analysis. Finally, key findings and implications will be highlighted, followed by a discussion of research limitations, suggestions for future research, and conclusions.

\section{Literature Review}

\subsection{KM Strategy and KM Performance}

Since knowledge has been regarded as a strategic resource for organizations (Abou-Zeid, 2003; Choi \& Lee, 2002; Conner \& Prahalad, 1996; Kogut \& Zander, 1992), it is important to know how to effectively manage other resources (e.g., people, process, IT) to comply with knowledge. KM strategy is the right tool to determine how to employ these various resources to enhance knowledge quantity and quality, thus, are regarded as the facilitators for KM outcomes (Beckman, 1999; Hansen et al., 1999, Zack, 1999a).

Various KM strategies development are classified by the nature of knowledge itself, (e.g., explicit or tacit) (Shih \& Chiang, 2005; Polanyi, 1997). Explicit knowledge refers to transfer information in a systematized manner, whereas tacit knowledge refers to transfer information through social networks among employees. These two concepts are similar to that of Hansen et al.'s (1999) classification for KM strategy as "codification strategy" which is also called "system strategy" and "personalization strategy" which is also called "human strategy" respectively. While codification strategy of KM adopted, it seeks to retrieve and store knowledge in explicit form (e.g., in information systems or databases) that can be easily transferred and reused by individuals in an organization. The personalization strategy of KM, on the other hand, seeks to capture and share tacit knowledge that resides in human minds, behavior, and perception. It evolves from person-to-person interact extensively to obtain knowledge. In other words, various IT strategies for firms must support the adoption of different KM strategies.

The rapid progress of IT provides a good solution to answer the question: why does a KM project alone not always lead to enhanced business performance when firms overlook its links to other resources? That is, firms with excellent IT capabilities allow them to cope with the present competitive and dynamic environment well (Bhatt \& Grover, 2005). Accordingly, strategic IT management has been regarded an enabler in business performance, when it fits with certain aspects of the KM context, helping companies to survive in the highly competitive business environment (Alavi \& Leidner, 2001).

Choosing the right ITs for different KM strategies is critical for organizations (Kim, 2001). Effective KM activities require employing KM strategies, as well as IT, appropriately (Mahapatra \& Sarkar, 2000). Using various IT solutions to comply with KM strategy will contribute to the creation of corporate knowledge directories, via knowledge mapping or the building of knowledge networks (Wakefield, 2005). Therefore, the relationship between KM strategy and IT strategy is highly relevant (Fehér, 2002). Meanwhile, according to the arguments presented by Asoh (2004), as an enabler for KM and IM/IS, IT strategy serves as the delivery-oriented component (Earl, 1989) that must be aligned with KM strategy to improve both KM and organizational performance. In the context of the KM development environment, higher KM capability requires a high quality of IT relatedness, which, in turn, depends upon how well their relationships have been modeled (Tanriverdi, 
2005; Sher \& Lee, 2004; Tippins \& Sohi, 2003; Gold et al., 2001; Grover \& Davenport, 2001). It means that an organization's KM strategy should provide direction in determining how IT can support knowledge activities within the organization (Scheepers et al., 2004; Earl, 2001; Davenport et al., 1996).

IT strategy can be classified into two general categories: IT environment scanning; and strategic use of IT (Bergeron et al., 2004). System KM strategy requires IT tools that allow for explicit knowledge to be formalized and articulated in documents and shared electronically through IT infrastructures such as intranets (Scott, 1998). In this manner, organizations should invest in an extensive IT system to codify knowledge. Therefore, a firm's IT strategy should focus on paying more attention to the strategic use of IT internally, in order to improve the quality and quantity of electronic repositories or databases. In contrast, human KM strategy draws upon interpersonal relationships to exchange and share tacit knowledge across the organization. Thus, firms need a moderate investment in IT to connect experts in the organization. The technologies may include an e-mail system, on-line discussion networks, videoconferencing, and other collaborative tools (Scheepers et al., 2004). A firm's IT strategy, therefore, should aim at scanning the external IT environment, searching for communication tools and other interactive technologies to support person-to-person knowledge-sharing.

Accordingly, the right IT strategy used will depend upon what KM strategy an organization employed. Hence, the following hypothesis is proposed:

\section{H1: KM strategy has a positive direct effect on IT strategy.}

According to the perspectives of explicit-oriented and tacit-oriented, Choi and Lee (2003) classified KM methods into four styles, labeled dynamic, system-oriented, human-oriented, and passive. After empirical test from 54 Korean firms in the manufacturing, service, and financial industries, they indicate that dynamic style integrating explicit-oriented with tacit-oriented methods is found to have a significant impact on performance. On the case study of 31 different KM projects in 23 countries, Davenport and Prusak (1998) propose a four KM projects typology, namely knowledge repositories, knowledge access, knowledge environment, and knowledge assets. They further manifest the factors that lead to successful KM projects, including knowledge-oriented culture, technical and organizational infrastructure, senior management support, clarity of vision and language, linking KM to economic benefits, nontrivial motivational aids, multiple channels for knowledge transfer, and the level of knowledge structure. Finally, in a survey of $32 \mathrm{KM}$ professionals, Singh (2000) indicates that the activities of KM value chain, including five primary knowledge activities (i.e., acquisition, selection, generation, integration, and externalization) and four secondary activities (i.e., leadership, coordination, control, and measurement), were found to have a positive relationship to competitive advantages in terms of perceived productivity, reputation, agility, and innovation. In sum, much evidences have been suggested that develop a KM strategy provides a valuable opportunity to obtain a greater understanding of the way a business operates to foster their KM practices to success (Garavelli et al., 2004; Iqbal et al., 2018; Robertson, 2004). Consequently, the following hypothesis is proposed:

H2: KM strategy has a positive direct effect on KM performance.

It has been realized that successful KM projects will lead to overall organizational performance (Davenport \& Prusak, 1998; Argote \& Ingram, 2000). However, such linkage is indefinite and difficult to validate clearly (Yu et al., 2004). That is, it means that there is still unexplored evidence to prove the direct relationship between knowledge-related antecedents and organizational performance, since lots of factors may contribute to the organizational performance (Lee \& Choi, 2003; Ostroff \& Schmitt, 1993). As Lee and Choi (2003) describe "this incorporation may help confirm that enablers ultimately create business value." (p. 182). Thus, an intermediate outcome (e.g., knowledge quality, user knowledge satisfaction, or organizational creativity) may be introduced as a mediator in the causal relationship (Lee \& Choi, 2003, Yu et al., 2004).

H3: KM performance has a positive direct effect on business performance.

\subsection{IT Strategy and IT Performance}

IT strategy is concerned with technology policies including questions of architecture, security levels, etc. (Earl, 1989). In Henderson and Venkatraman's (1993) strategic alignment model, IT strategy involves three components that should be articulated in terms of internal and external domains: information technology scope, systemic competencies, and IT governance. In the perspective of information-processing requirements, IT strategy has been conceptualized as a four-dimensional construct, namely competencies, role of IT, systems design and development, and infrastructures (Das et al., 1991). According to Bergeron et al. (2004), two dimensions are identified within IT strategy, the first one is IT environment scanning, representing the capability of a firm to detect and react to external changes in technology; the second one is strategic use of IT, representing 
what extent a firm used IT to increase product quality and performance. In Earl's (1989) research, he contends that there are three levels of IS-related strategy, labeled IM (information management) strategy, IS (information system) strategy, and IT (information technology) strategy, wherein IT strategy deals with the technology used for delivery of application systems and has been defined as "the portion of an organization's overall strategy that related to the IT groups." (Blanton et al., 1992, p. 535).

Numerous successful stories involving strategic utilization of IT have been described in the literature (Sabherwal \& Grant, 1994). While many researchers have indicated that IT has a significant positive direct effect on organizational outcome, however, enough of exceptions have been argued to contest with the argumentation (Barua \& Lee, 1997; Markus \& Soh, 1993; Quinn \& Baily, 1994; Clemons \& Row, 1991). This premise is similar to the influential processes of KM process-KM intermediate outcome-organizational performance aforementioned. As Henderson and Venkatraman (1993) contend "Indeed, the key strategic IT management challenge lies in the identification of those strategic dimensions that require modification under different contingencies for enhancing organizational performance". It means that IT strategy should be aligned with its business strategy or other meaningful activities, thus, the direct maximum effectiveness for organizations can be achieved, or the performance would be formed by an indirect effect form IT strategy to business performance through IT outcome.

H4: IT strategy has a positive direct effect on IT performance.

H5: IT performance has a positive direct effect on business performance.

Furthermore, numerous of studies have pointed out that suitable or successful IT implementations are enablers for effective KM activities (Alavi \& Leidner, 2001; Choi \& Lee, 2002; Kankanhalli et al., 2003; Nonaka \& Konno, 1998; Zack, 1999b). It means that for achieving KM performance requires IT deployment well to enhance the KM outcome (Mahapatra \& Sarkar, 2000). Thus, the following hypothesis is also proposed:

H6: IT performance has a positive direct effect on KM performance.

\section{Methodology}

\subsection{Measurement Development}

Five constructs were measured in this study, including KM strategy, IT strategy, KM performance, IT performance, and business performance. A multiple-item method was used to form the questionnaires. Each item was used in 7-point Likert scales, ranging from " $1=$ strongly disagree" to " $7=$ strongly agree". Wherever possible, for the measurement validity, this study adopted well-established research instruments, with only minor changes in wording. Most of the independent and dependent variables were operationalized, based upon the pertinent existing literature.

\subsubsection{KM Strategy}

Researchers contend that KM strategy is different from knowledge strategy (Asoh, 2004; Zack, 2002). Knowledge strategy is operationalized as "knowledge-related guidelines on what individuals or groups of individuals know or need to know, and on how to develop and deploy the required knowledge to ensure organizational objectives." (Asoh, 2004, p. 72). Then, KM strategy in our study is defined as "the set of tactical and/or operational activities executed by an organization in response to its knowledge strategy." According to Hansen et al. (1999), KM strategy includes two components: system strategy and human strategy. We measure it by using 8 items adapted from Choi and Lee's (2002) self-developed instrument in their study. The measurement items are listed in Table 1.

Table 1. Item Measures of KM Strategy

\begin{tabular}{ll}
\hline Construct & Item \\
\hline & kss1: In my organization, our knowledge (know-how, technical skill, or problem solving methods) is well \\
& codified. \\
System & kss2: In my organization, our knowledge can be acquired easily through formal documents and manuals. \\
& kss3: In my organization, results of our projects and meetings should be documented. \\
& kss4: In my organization, our knowledge is shared in codified forms like manuals or documents. \\
& ksh1: In my organization, our knowledge can be easily acquired from experts and co-workers. \\
& ksh2: In my organization, it is easy to get face-to-face advice from experts. \\
Human & ksh3: In my organization, informal dialogues and meetings are used for knowledge sharing. \\
& ksh4: In my organization, our knowledge is acquired by one-to-one mentoring.
\end{tabular}




\subsubsection{IT Strategy}

This present research followed the definition of IT strategy proposed by Blanton et al. (1992) as: "the portion of an organization's overall strategy that relates to the IT group"). According to Bergeron et al. (2004), IT strategy includes two dimensions: IT environment scanning, representing the extent the firm's capability to detect and react to technological changes relative to its competitors; and strategic use of IT, representing the extent to which firms use IT to improve their productivity, profitability, quality and performance. This present study measured IT strategy using 11 items also derived from Bergeron et al.'s (2004) self-developed items in their study, which are listed in Table 2.

Table 2. Item Measures of IT Strategy

\begin{tabular}{ll}
\hline Construct & Item \\
\hline & iye1: In my organization, we use an external information network to identify our requirements in \\
& information technology. \\
& iye2: In my organization, we know the information technology used by our competition. \\
iye3: In my organization, we institute a technology watch in order to rapidly change our information \\
scanning & technology when necessary. \\
& iye4: In my organization, we ensure that our choice of information technology follows the evolution of \\
& our environment. \\
& iye5: In my organization, we use the information technologies that will permit a rapid reaction to \\
& environmental pressure. \\
\hline iyu1: In my organization, we use IT to reduce our production costs. \\
iyu2: In my organization, we use IT to generate substantial savings. \\
iyu3: In my organization, we use IT to improve our firm's productivity. \\
it & iyu4: In my organization, we use IT to increase our firm's profitability. \\
& iyu6: In my organization, we use IT to respect the deadlines requested by our customers.
\end{tabular}

\subsubsection{KM Performance}

KM performance is defined as "the measures of knowledge quality and user satisfaction of the firm through its business endeavors and deployment of KM resources." As knowledge-based view of a company has emerged as an important issue in strategic management researchers and practitioners, it is important to know how to develop appropriate metrics to assess the effectiveness of KM (Chen \& Chen, 2006; Lee et al., 2005; Ahn \& Chang, 2004; Schultze \& Leidner, 2002). According to a literature review from 1995 to 2004, Chen and Chen (2006) point out that although quantitative analysis is the primary methodology used to evaluate KM performance, it demonstrates a tendency toward using non-financial factors (subjective perceptions) for KM performance assessment in a social and behavioral sciences approach. Thus, we adopt this argument by using subjective measures to evaluate KM performance.

The instrument is adapted from that of Yu et al.'s (2004) self well-defined measures in their study. It is composed of 10 items which fall into two dimensions: knowledge quality (5 items) and user knowledge satisfaction (5 items). The measurement items are listed in Table 3.

Table 3. Item Measures of KM Performance

\begin{tabular}{cl}
\hline Construct & Item \\
\hline & Knowledge provided by a knowledge management system ... \\
& kql1: is relevant to our business and tasks. \\
Knowledge & kql2: is comprehensive so that it can cover all contents required by our business and tasks. \\
Quality & kql3: is reliable. \\
& kql4: is accurate. \\
& kq15: is of good quality on the whole. \\
\hline User Knowledge & I am satisfied with ... \\
Satisfaction & uks1: the quality and quantity of knowledge available at the KM system. \\
& uks2: the capability with which I can search and obtain knowledge necessary to me.
\end{tabular}


uks3: various functions provided by the KM system.

uks4: the evaluation and reward systems in knowledge management.

uks5: organizational management of knowledge.

\subsubsection{IT Performance}

IT performance is defined as "the measures of user satisfaction and organizational impact of the firm through its business endeavors and deployment of IT resources." Eight items were used to measure IT performance. The instrument was derived from the measurement items that Chan et al. (1997) developed in their study and modified from IS to IT measurement context in this present study. We employed two key dimensions as the proxies for measuring IT performance. The first one is user information satisfaction (3 items), which is a short form for the user information satisfaction (UIS) instrument with a minor change to comment on their satisfaction with company systems. The second one is IT organizational impact ( 5 items) designed to measure respondents' perceptions about the impacts on business productivity, competitive position, and financial performance, as well as the overall performance. The measurement items are listed in Table 4.

Table 4. Item Measures of IT Performance

\begin{tabular}{cl}
\hline Construct & Item \\
\hline \multirow{2}{*}{ UIS } & itu1: I am satisfied with IS/IT staff and services. \\
& itu2: I am satisfied with the information product. \\
& itu3: I am satisfied with end user knowledge.
\end{tabular}

ito1: IT has dramatically increased our productivity.

Organizational impact ito3: IT has dramatically increased our sales.

ito4: IT has dramatically increased our profitability.

ito5: IT has improved our overall performance.

\subsubsection{Business Performance}

Since conceptualization and operationalization of business performance is a difficult issue in strategy research (Venkatraman \& Ramanujam, 1986), strategic management and IS/IT researchers have offered a variety of measures of organizational performance. Dess and Robinson (1984) argue that, while measuring organizational performance, the subjective approach and the objective approach produce similar results. According to Khandwalla (1977), subjective measures are widely used instead of objective measures, because subjective measures have been shown to capture a broad concept like business performance. In the IS/IT research, several studies (e.g., Croteau \& Raymond, 2004; Chan et al., 1997; Bergeron \& Raymond, 1995; Venkatraman, 1989) have used the subjective approach successfully to investigate the relationship between strategy and business performance. Consequently, this study employs subjective measures of business performance.

Business performance is defined as 'the measures of growth and profitability of the firm through its business endeavors and deployment of organizational and technology resources'. Of all 8 items which were derived from Venkatraman (1989), involving 7-point Likert scales. The respondents were asked to indicate their perceptions of how their firm performs relative to the main competitor in the market on 2 dimensions (i.e., growth and profitability) in term of sales growth rate, market share gains, ROI, net profit, return on sales, and financial liquidity. Table 5 lists the original business performance items used in our research.

Table 5. Item Measures of Business Performance

\begin{tabular}{ll}
\hline Construct & Item \\
\hline \multirow{3}{*}{ Growth } & opg1: The sales growth position has been outstanding relative to competition. \\
& opg2: The sales growth has been outstanding relative to competition. \\
& opg3: The market share gains have been outstanding relative to competition. \\
\hline & opp1: The return of corporate investment has been outstanding relative to competition. \\
& opp2: The net profit position has been outstanding relative to competition. \\
Profitability & opp3: The ROI position has been outstanding relative to competition. \\
& opp4: The return on sales has been outstanding relative to competition. \\
& opp5: The financial liquidity position has been outstanding relative to competition.
\end{tabular}




\subsection{Pretest}

The initial version of this instrument was pretested for content validity using samples of two MIS professors and five experts in the KM field. Participants were asked to examine the survey instruments and comment on its format and length, as well as on the wording of each individual item. Ambiguous items were reworded, based upon participant feedback.

\subsection{Unit of Analysis}

In survey research, distributing the questionnaire to the right person is critical. The unit of analysis in our research was an organization or strategic business unit (SBU). Respondents needed to be knowledgeable about the nature of their KM activities, IT deployment, and performance of KM, IT, and business. Thus, executives (CIO, CEO, CKO, Directors) and those who were responsible for devising KM within a command tent were felt to be the right individuals to answer our questionnaire.

\subsection{Data Collection Procedure}

We used a cross-sectional mailed survey for data collection. Mailing lists were excerpted from the Common Wealth Magazine database, which includes the top 1000 companies in the manufacturing industry, the top 500 companies in the service industry, and the top 100 companies in the finance/banking industry in Taiwan. The reason we chose the top-ranked companies in each industry was that they are the best performing companies in Taiwan. We were interested in finding out the prevalence of KM strategic alignment in successful companies.

\section{Data Analysis and Results}

\subsection{Sample Characteristics}

The characteristics of the sample are shown in Table 7. The largest number of respondents came from the manufacturing industry, representing 57.1 percent of the responding companies. The largest share of the companies had 100 to 499 employees (37.9\%). Even though the questionnaires were sent to executive officers, the respondents held various job titles, including the top manager, middle manager, and first-line manager, among others. Approximately $60 \%$ of the respondents had more than 6 year's experiences within the current firm. This suggests that the respondents had enough experience and knowledge to complete the questionnaire. The largest proportion (47.2\%) had an undergraduate degree. The age of the participants ranged from 21 to 51 and above, with the largest percentage (39.8\%) in the 31 to 41 category. About $75 \%$ of the respondents were male.

\subsection{Descriptive Statistics}

The means, standard deviations, and the matrix of intercorrelations among the variables are shown in Table 6 . The correlation matrix indicates that both of growth and profitability business performance were highly correlated with all KM strategy (system and human), IT strategy (IT environment scanning and strategic use of IT), KM performance variables (knowledge quality and user knowledge satisfaction), IT performance (user information satisfaction and organizational impact). It also indicates that the independent variables were significantly inter-correlated, at the $\mathrm{p}<0.01$ level.

Table 6. Descriptive Statistics and Intercorrelations

\begin{tabular}{llllllllllll}
\hline Variable & Mean & S.D. & 1 & 2 & 3 & 4 & 5 & 6 & 7 & 8 & 9 \\
\hline 1. kss & 4.84 & 0.85 & & & & & & & & & \\
2. ksh & 4.70 & 0.83 & 0.68 & & & & & & & & \\
3. iye & 5.01 & 0.89 & 0.54 & 0.61 & & & & & & & \\
4. iyu & 5.14 & 0.88 & 0.62 & 0.61 & 0.72 & & & & & & \\
5. kql & 4.73 & 0.86 & 0.59 & 0.50 & 0.58 & 0.61 & & & & & \\
6. uks & 4.53 & 0.87 & 0.62 & 0.56 & 0.58 & 0.65 & 0.82 & & & & \\
7. itu & 4.84 & 0.90 & 0.49 & 0.56 & 0.61 & 0.61 & 0.57 & 0.68 & & & \\
8. ito & 4.75 & 0.98 & 0.46 & 0.51 & 0.60 & 0.69 & 0.56 & 0.67 & 0.75 & & \\
9. opg & 4.49 & 1.06 & 0.39 & 0.44 & 0.33 & 0.38 & 0.40 & 0.49 & 0.44 & 0.45 & \\
10. opp & 4.42 & 1.04 & 0.42 & 0.44 & 0.31 & 0.39 & 0.40 & 0.48 & 0.44 & 0.47 & 0.87 \\
\hline
\end{tabular}

Note: $1 . n=161$.

2. All correlations are significant at the $\mathrm{p}<0.01$ level (2-tailed).

3. kss: system; ksh: human; iye: IT environment scanning; iyu: strategic use of IT; kql: knowledge quality; uks: user knowledge satisfaction; itu: user information satisfaction; ito: organizational impact; opg: growth; opp: profitability. 


\subsection{Assessment of Construct Validity}

A Structural Equation Modeling with the PLS (Partial Least Square) technique was used to assess the measurement model. The validity of the research constructs was assessed using estimation and respecification of the measurement model by confirmation factor analysis (CFA).

The important step in scale validation is to assess the strength of measurement between the items and associated constructs. In the estimated model, items that demonstrate cross load, poor loadings and poor reliability were dropped and the model was re-estimated. This was done to ensure that data are a good fit with the measurement. We used the value of 0.5 as the threshold for factor loading assessment (Hair et al., 2006). As a result (see Table 7), ksp4 was deleted because of the poor loadings to explain its underlying construct. After dropping this item, the CFA model is re-estimated again to ensure that data are a good fit with the measurement model.

In addition, to cross-validate these constructs, other methods were used to reconfirm the construct validity and reliability. According to Bagozzi and Yi (1988) and Fornell and Lacker (1981), a perfect measurement model for research must satisfy three types of reliability: (1) individual item reliability should be as large as possible; (2) reliability for the composite of measurements of a latent variable should exceed 0.6 ; and (3) the average variance extracted (AVE) from a set of measurements of a latent variable should exceed 0.5. Furthermore, the value of AVE can also be used to discern convergent validity (Fornell \& Larcker 1981; Hair et al. 2006). Table 7 illustrates that the values of individual item reliability and composite reliability of the constructs are all adequate. Variance extracted estimates, as discussed by Fornell and Larcker (1981), were used to assess the average variance extracted for all constructs, suggesting that a value of 0.5 or larger is adequate. As we can see in Table 7 , the values of AVE for all constructs are ranging from 0.74 to 0.92 demonstrating a reasonable degree of convergent validity.

Table 7. Scale Properties for the Measurement Model

\begin{tabular}{|c|c|c|c|c|c|c|}
\hline Construct indicators & Standardized loadings ${ }^{1}$ & Standard Error & $\mathrm{T}$ value & $\mathrm{IIR}^{2}$ & $\mathrm{CR}^{3}$ & $\mathrm{AVE}^{4}$ \\
\hline \multicolumn{7}{|l|}{ KM strategy } \\
\hline System & 0.89 & 0.011 & 44.22 & 0.79 & \multirow[t]{5}{*}{0.93} & \multirow[t]{5}{*}{0.77} \\
\hline kss1 & 0.86 & 0.022 & 39.81 & 0.74 & & \\
\hline kss2 & 0.89 & 0.020 & 43.95 & 0.79 & & \\
\hline kss3 & 0.84 & 0.029 & 28.85 & 0.71 & & \\
\hline kss4 & 0.91 & 0.015 & 61.40 & 0.83 & & \\
\hline Human & 0.94 & 0.020 & 88.87 & 0.88 & \multirow[t]{4}{*}{0.91} & \multirow[t]{4}{*}{0.76} \\
\hline ksp1 & 0.89 & 0.018 & 49.76 & 0.79 & & \\
\hline ksp2 & 0.91 & 0.015 & 61.29 & 0.83 & & \\
\hline ksp3 & 0.82 & 0.036 & 22.92 & 0.67 & & \\
\hline \multicolumn{7}{|l|}{ IT strategy } \\
\hline IT environment scanning & 0.91 & 0.014 & 66.86 & 0.83 & \multirow[t]{6}{*}{0.94} & \multirow{6}{*}{0.74} \\
\hline iye1 & 0.81 & 0.037 & 21.54 & 0.66 & & \\
\hline iye 2 & 0.80 & 0.040 & 19.82 & 0.64 & & \\
\hline iye3 & 0.90 & 0.016 & 55.21 & 0.81 & & \\
\hline iye4 & 0.90 & 0.018 & 49.75 & 0.81 & & \\
\hline iye 5 & 0.88 & 0.024 & 36.74 & 0.77 & & \\
\hline Strategic use of IT & 0.94 & 0.008 & 119.09 & 0.88 & \multirow{7}{*}{0.95} & \multirow{7}{*}{0.77} \\
\hline iyu1 & 0.89 & 0.018 & 49.28 & 0.79 & & \\
\hline iyu2 & 0.86 & 0.030 & 28.11 & 0.74 & & \\
\hline iyu3 & 0.90 & 0.019 & 46.40 & 0.81 & & \\
\hline iyu4 & 0.88 & 0.029 & 30.12 & 0.77 & & \\
\hline iyu5 & 0.88 & 0.022 & 38.77 & 0.77 & & \\
\hline iyu6 & 0.85 & 0.035 & 24.15 & 0.72 & & \\
\hline \multicolumn{7}{|l|}{ KM performance } \\
\hline Knowledge quality & 0.96 & 0.010 & 97.79 & 0.92 & \multirow{4}{*}{0.95} & \multirow{4}{*}{0.80} \\
\hline kql1 & 0.84 & 0.031 & 26.65 & 0.71 & & \\
\hline $\mathrm{kq12}$ & 0.88 & 0.029 & 29.99 & 0.77 & & \\
\hline $\mathrm{kql3}$ & 0.93 & 0.016 & 56.02 & 0.87 & & \\
\hline
\end{tabular}




\begin{tabular}{|c|c|c|c|c|c|c|}
\hline $\mathrm{kq} 14$ & 0.94 & 0.013 & 71.44 & 0.88 & & \multirow{8}{*}{0.80} \\
\hline $\mathrm{kq} 15$ & 0.88 & 0.024 & 36.20 & 0.77 & \multirow{7}{*}{0.95} & \\
\hline User knowledge satisfaction & 0.96 & 0.007 & 127.97 & 0.92 & & \\
\hline uks1 & 0.92 & 0.019 & 45.29 & 0.85 & & \\
\hline uks2 & 0.79 & 0.037 & 21.01 & 0.62 & & \\
\hline uks3 & 0.93 & 0.015 & 60.64 & 0.87 & & \\
\hline uks4 & 0.91 & 0.018 & 49.26 & 0.83 & & \\
\hline uks5 & 0.92 & 0.013 & 73.60 & 0.85 & & \\
\hline \multicolumn{7}{|l|}{ IT performance } \\
\hline User information satisfaction & 0.90 & 0.016 & 57.77 & 0.81 & \multirow{4}{*}{0.95} & \multirow{4}{*}{0.86} \\
\hline itu1 & 0.90 & 0.022 & 41.82 & 0.81 & & \\
\hline itu2 & 0.96 & 0.008 & 121.02 & 0.92 & & \\
\hline itu3 & 0.92 & 0.016 & 55.87 & 0.85 & & \\
\hline Organizational impact & 0.96 & 0.006 & 161.39 & 0.92 & \multirow{6}{*}{0.97} & \multirow{6}{*}{0.85} \\
\hline ito1 & 0.92 & 0.013 & 68.66 & 0.85 & & \\
\hline ito2 & 0.94 & 0.009 & 96.89 & 0.88 & & \\
\hline ito3 & 0.95 & 0.011 & 86.56 & 0.90 & & \\
\hline ito4 & 0.93 & 0.011 & 84.09 & 0.87 & & \\
\hline ito5 & 0.87 & 0.039 & 22.48 & 0.76 & & \\
\hline \multicolumn{7}{|l|}{ Business performance } \\
\hline Growth & 0.95 & 0.007 & 130.04 & 0.90 & \multirow{4}{*}{0.97} & \multirow{4}{*}{0.92} \\
\hline opg1 & 0.96 & 0.017 & 94.50 & 0.92 & & \\
\hline opg2 & 0.97 & 0.011 & 214.89 & 0.94 & & \\
\hline opg3 & 0.94 & 0.010 & 94.84 & 0.88 & & \\
\hline Profitability & 0.98 & 0.003 & 302.08 & 0.96 & \multirow{6}{*}{0.97} & \multirow{6}{*}{0.85} \\
\hline opp1 & 0.92 & 0.016 & 57.54 & 0.85 & & \\
\hline орp2 & 0.96 & 0.009 & 103.62 & 0.92 & & \\
\hline opp3 & 0.95 & 0.009 & 106.19 & 0.90 & & \\
\hline opp4 & 0.96 & 0.007 & 129.31 & 0.92 & & \\
\hline opp5 & 0.82 & 0.039 & 21.20 & 0.67 & & \\
\hline
\end{tabular}

Note:

${ }^{1}$ All item loadings $(\lambda)$ are significant at $\mathrm{p}<0.05$ level

${ }^{2}$ Individual item reliability $($ IIR $)=(\text { Standardized loadings })^{2}$

${ }^{3}$ Composite reliability $(\mathrm{CR})=(\Sigma \mathrm{Li}) 2 /((\Sigma \mathrm{li}) 2+\Sigma \operatorname{var}(\mathrm{Ei}))$

${ }^{4}$ Average variance extracted $(\mathrm{AVE})=\Sigma \operatorname{li} 2 /(\Sigma \operatorname{li} 2+\Sigma \operatorname{var}(\mathrm{Ei}))$

Finally, discriminant validity was assessed by the variance extracted test proposed by Fornell and Larcker (1981). As can be seen in Table 8, the square root of variance extracted estimates for any pair of two factors was compared to the correlation between the two constructs. If both variance extracted estimates are greater than the squared correlation, then discriminant validity is demonstrated. The results of the variance extracted tests show that discriminant validity is supported since each squared correlation is less than both applicable variance extracted estimates.

Table 8. Intercorrelations and AVEs

\begin{tabular}{|c|c|c|c|c|c|c|c|c|c|c|}
\hline Construct & kss & ksp & iye & iyu & $\mathrm{kql}$ & uks & itu & ito & opg & opp \\
\hline kss & 0.88 & & & & & & & & & \\
\hline ksp & 0.68 & 0.87 & & & & & & & & \\
\hline iye & 0.54 & 0.61 & $\mathbf{0 . 8 6}$ & & & & & & & \\
\hline iyu & 0.62 & 0.61 & 0.72 & 0.88 & & & & & & \\
\hline kql & 0.59 & 0.50 & 0.58 & 0.61 & 0.89 & & & & & \\
\hline uks & 0.62 & 0.56 & 0.58 & 0.65 & 0.82 & 0.89 & & & & \\
\hline itu & 0.49 & 0.56 & 0.61 & 0.61 & 0.57 & 0.68 & 0.93 & & & \\
\hline
\end{tabular}




\begin{tabular}{lllllllllll}
\hline ito & 0.46 & 0.51 & 0.60 & 0.69 & 0.56 & 0.67 & 0.75 & $\mathbf{0 . 9 2}$ & & \\
opg & 0.39 & 0.44 & 0.33 & 0.38 & 0.40 & 0.49 & 0.44 & 0.45 & $\mathbf{0 . 9 6}$ & \\
opp & 0.42 & 0.44 & 0.31 & 0.39 & 0.40 & 0.48 & 0.44 & 0.47 & 0.87 & $\mathbf{0 . 9 2}$ \\
\hline
\end{tabular}

Note: 1. kss: system; ksp: human; iye: IT environment scanning; iyu: strategic use of IT; kql: knowledge quality; uks: user knowledge satisfaction; itu: user information satisfaction; ito: organizational impact; opg: growth; opp: profitability.

2. Diagonal elements (in bold) represented the square root of Average Variance Extracted $(=\Sigma \operatorname{li} 2 /(\Sigma \operatorname{li} 2+\Sigma \operatorname{var}(\operatorname{Ei})))$, while off-diagonal elements were represented by the correlation coefficient among constructs. For discriminant validity, diagonal elements should be larger than off-diagonal elements.

\subsection{Hypothesis Testing}

The test results of the structure are summarized in Figure 1. Overall, all of the six paths exhibited significance at the $\mathrm{p}<0.05$ level providing strong support for the proposed model of KM and IT strategy on KM, IT and business performance. The results showed that, consistent with $\mathrm{H} 1$ and $\mathrm{H} 2, \mathrm{KM}$ strategy has significant direct effects on IT strategy $(\gamma=0.70, \mathrm{p}<0.001)$ and KM performance $(\gamma=0.38, \mathrm{p}<0.001)$. Consistent with H4, Figure 1 also showed that IT strategy has a positive direct effect on IT performance $(\beta=0.73, p<0.001)$ with a variance explanation of $53 \%$., and then IT performance has a positive direct effect on KM performance $(\beta=0.48$, $\mathrm{p}<0.001)$. Thus, $\mathrm{H} 4$ and $\mathrm{H} 6$ are supported. As expected, business performance can be predicted by IT performance and KM performance, explaining $28.2 \%$ of the business performance variance. The path from IT performance $(\beta=0.33, \mathrm{p}<0.001)$ is stronger than that of KM performance $(\beta=0.25, \mathrm{p}<0.01)$. Thus, H3 and H5 are also supported.

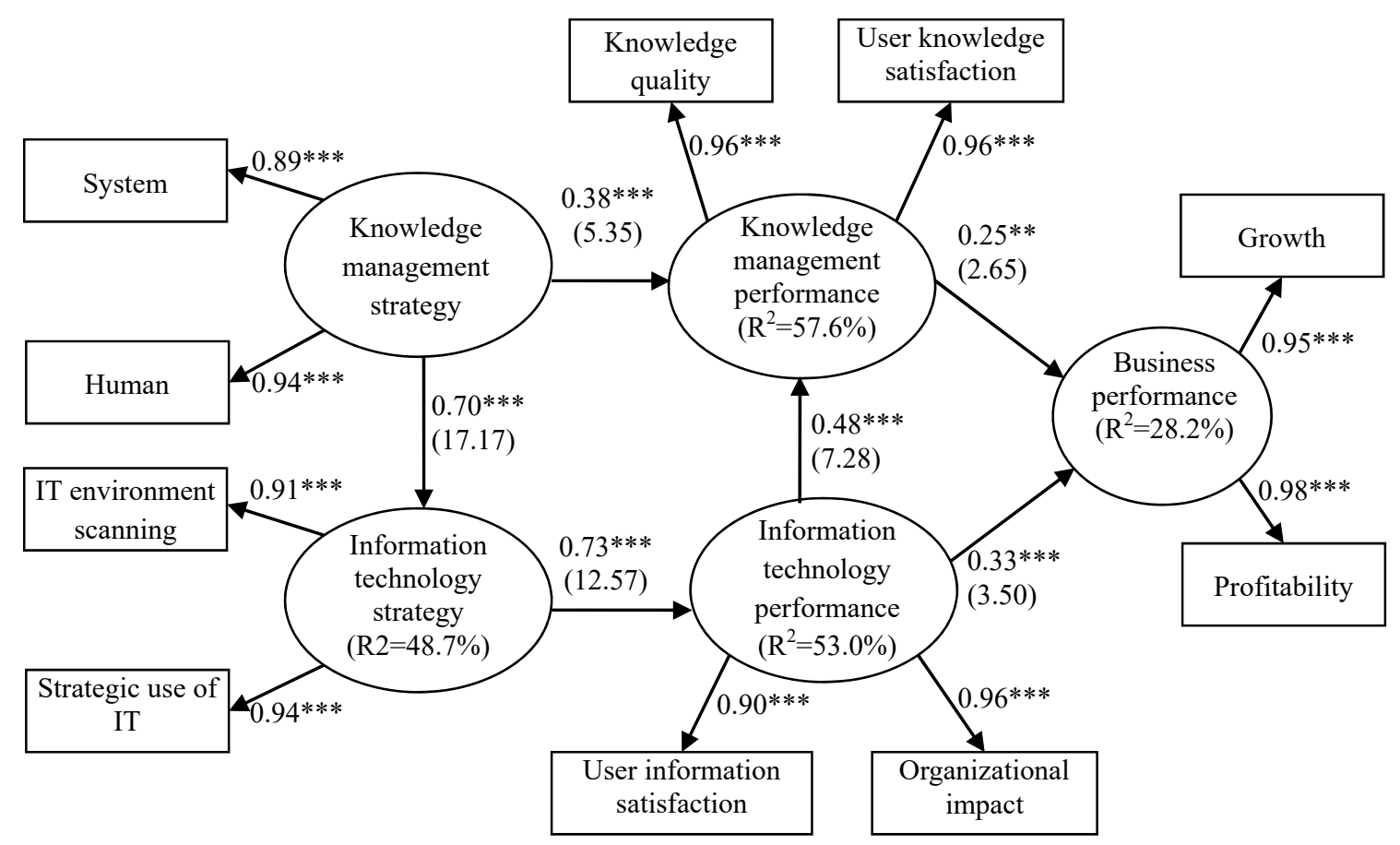

Note: Values in the parentheses are T values; *** $\mathrm{p}<0.05$

Figure 1. Results of Structural Equation Modelling

\section{Discussion and Conclusions}

\subsection{Key Findings and Discussion}

This present research subscribed to the call for the strategic orientation of KM and IT and to test their effects on performance. The results supported the hypotheses, demonstrating that KM strategy and IT strategy have significant positive effects on KM performance and IT performance respectively, and then collectively, have 
impacts on business performance.

\subsection{Implications for Researchers}

Consistent with the perspectives aforementioned, the emerging body of literature on KM depicts that co-aligned among properties of KM, units, relationships, and environment leads to superior organizational performance as well as KM and IT outcomes (Argote et al., 2003) than that of misalignment, and the relative effectiveness of the types varies with context. Several evidences have been concluded of this conclusion. In this vein, we describe the high-level model briefly below in order to provide a rationale for more detailed discussions about the underlying meanings of KM and IT strategic orientation for performance that follows. Although the contribution of successful KM projects to an organization is widely acknowledged, how to attain KM performance or organization performance remains an unsolved question. Fortunately, the capabilities of IT to support communications, collaboration, and those searching for knowledge to enable collaborative learning for KM are confirmed. That is, firms that have excellent IT capabilities allow them to be able to cope with the present competitive and dynamic environment well (Bhatt \& Grover, 2005). Accordingly, in order to survive in the highly competitive business environment, the content of strategic IT management could be regarded as a complement activity for KM to achieve KM performance, when fitting with certain aspects of KM context is to stimulate researchers' deep though in this topic (Alavi \& Leidner, 2001).

In short, our research echoed to the point of views for previous studies in terms of the research implications suggested by the strategy of KM in cultivating and developing IT capabilities and strategy to meet performance (Alavi \& Leidner, 2001; Davenport \& Prusak, 1998; Wiig, 1995). Choosing the right ITs for different KM strategies is critical for organizations (Kim, 2001). Improved performance requires appropriate employing KM strategies as well as IT (Mahapatra \& Sarkar, 2000). By using various IT solutions comply with KM strategy will contribute to the creation of corporate knowledge directories through knowledge mapping or the building of knowledge networks (Wakefield, 2005). Therefore, the causal link between KM and IT strategy is highly important for firms to manage and design KM initiates (Fehér, 2002). Meanwhile, according to the arguments presented by Asoh (2004), as an enabler for KM and IM/IS, IT strategy serves as the delivery-oriented component (Earl, 1989) that need to be fit with KM strategy for improving KM performance and organizational performance. Thus, the following research could integrate both of two constructs this present proposed as the baseline variables to show their essentiality in this field.

\subsection{Implications for Practitioners}

This research demonstrates that the relationships between KM strategy, IT strategy, and KM/IT performance are conspicuously linked to business performance. The evidence support prior research findings in large firms and imply that KM-IT relationships affect business performance. The underlying meaning of this study is that using KM strategy will lead to higher performance. Firms also must consider critical complementary resources to synthesize the effects of KM practices. Ideally, selecting and managing IT effectively in KM projects is the way to success, because effective IT governance mechanisms and aligns with business strategy will demonstrate a higher organizational performance in terms of supporting new product development, product diversification, and differentiation strategies (Ağan, et al., 2018; Wu et al., 2015).

This study also showed that it is useful to view the relationships between IT and KM as internal consistency or congruence. Firms should aim at integrating IT solutions in KM activities, rather than just focusing on KM strategies. For example, if firms try to develop social networks to promote the sharing of knowledge person-to-person, there must be a reward system encouraging this, and the company must scan the external IT environment and support the latest IT in order to enhance person-to-person communication. Companies that want to develop high-quality and reliable information systems to codify, store, disseminate, and reuse knowledge, must provide extensive training to employees, must have clear, definite job definitions, must tightly link compensation to work performance, and must use IT strategically to connect people with reusable codified knowledge. Only then will higher growth be achieved. All of the above benefits require that CEOs or managers take an active role in seeking IT strategy to support KM strategy.

\section{References}

Abou-Zeid, E. (2003). Developing business alignment knowledge management strategy. In E. Coakes (Ed.), Knowledge Management: Current Issues and Challenges (pp. 157-173), Hershey: Idea Publishing Group, Hershey, PA.

Ağan, Y., Acar, M. F., \& Erdogan, E. (2018). Knowledge management, supplier integration, and new product development. Knowledge Management Research \& Practice, 16(1), 105-117. 
https://doi.org/10.1080/14778238.2018.1428066

Ahn, J. H., \& Chang, S. G. (2004). Assessing the contribution of knowledge to business performance: The KP3 methodology. Decision Support System, 36(4), 403-416. https://doi.org/10.1016/S0167-9236(03)00029-0

Alavi, M., Yoo, Y., \& Vogel, D. R. (1997). Using information technology to add value to management education. Academy of Management Journal, 40(6), 1310-1333. https://doi.org/10.5465/257035

Alavi, M., \& Leidner, D. E. (1999). Knowledge management systems: Issues, challenges, and benefits. Communications of the AIS, 1(7), 1-36. https://doi.org/10.17705/1CAIS.00107

Alavi, M., \& Leidner, D. E. (2001). Review: Knowledge management and knowledge management systems: Conceptual foundations and research issues. MIS Quarterly, 25(1), 107-136. https://doi.org/10.2307/3250961

Argote, L., \& Ingram, P. (2000). Knowledge transfer: A basis for competitive advantage in firms. Organizational Behavior and Human Decision Processes, 82(1), 150-169. https://doi.org/10.1006/obhd.2000.2893

Argote, L., McEvily, B., \& Reagans, R. (2003). Managing knowledge in organizations: An integrative framework and review of emerging themes. Management Science, 49(4), 571-582. https://doi.org/10.1287/mnsc.49.4.571.14424

Asoh, D. A. (2004). Business and knowledge strategies: Alignment and performance impact analysis (Unpublished doctoral dissertation). University of New York.

Bagozzi, R. P., \& Yi, Y. (1998). On the evaluation of structural equation model. Journal of the Academy of Marketing Science, 16(1), 74-94. https://doi.org/10.1007/BF02723327

Baloh, P. (2007). The role of fit in knowledge management systems: Tentative propositions of the KMS Design. Journal of Organizational and End User Computing, 19(4), 22-41. https://doi.org/10.4018/joeuc.2007100102

Barney, J. B. (1986). Strategic factor markets: Expectations, luck, and business strategy. Management Science, 32(10), 1231-1241. https://doi.org/10.1287/mnsc.32.10.1231

Barney, J. B. (1991). Firm resources and sustained competitive advantage. Journal of Management, 17(1), 99-120. https://doi.org/10.1177/014920639101700108

Barua, A., \& Lee, B. (1997). An economic analysis of the introduction of an electronic data interchange system. Information Systems Research, 8(4), 398-422. https://doi.org/10.1287/isre.8.4.398

Beckman, T. (1999). The Current State of Knowledge Management. In Liebowitz (Ed.), Knowledge Management Handbook (pp. 1-22). Boca Raton: CRC Press.

Bergeron, F., \& Raymond, L. (1995). The contribution of IT to the bottom line: A contingency perspective of strategic dimensions. Proceedings of the International Conference on Information Systems (pp. 167-181). Amsterdam.

Bergeron, F., Raymond, L., \& Rivard, S. (2004). Ideal patterns of strategic alignment and business performance. Information \& Management, 41(8), 1003-1020. https://doi.org/10.1016/j.im.2003.10.004

Bhatt, G. D., \& Grover, V. (2005). Types of information technology capabilities and their role in competitive advantage: An empirical study. Journal of Management Information Systems, 22(2), 253-277. https://doi.org/10.1080/07421222.2005.11045844

Blanton, J. E., Watson, H. J., \& Moody, J. (1992). Toward a better understanding of information technology organization: A comparative case study. MIS Quarterly, 16(4), 531-555. https://doi.org/10.2307/249735

Chan, Y. E., Huff, S., Barclay, D. W. \& Copeland, D. G. (1997). Business strategic orientation, information systems strategic orientation, and strategic alignment. Information Systems Research, 8(2), 125-150. https://doi.org/10.1287/isre.8.2.125

Chen, M. Y., \& Chen, A. P. (2006). Knowledge management performance evaluation: A decade review from 1995 to 2004. Journal of Information Science, 32(1), 17-38. https://doi.org/10.1177/0165551506059220

Chen, Y. Y., \& Huang, H. L. (2012). Knowledge management fit and its implications for business performance: A profile deviation analysis. Knowledge-Based Systems, 27, 262-270. https://doi.org/10.1016/j.knosys.2011.11.012

Chen, Y. Y., Yeh, S. P., \& Huang, H. L. (2012). Does knowledge management "fit" matter to business 
$\begin{array}{llll}\text { performance. Journal of Knowledge } & \text { Management, }\end{array}$ https://doi.org/10.1108/13673271211262745

Choi, B., \& Lee, H. (2002). Knowledge management strategy and its link to knowledge creation process. Expert Systems with Applications, 23, 173-187. https://doi.org/10.1016/S0957-4174(02)00038-6

Choi, B., \& Lee, H. (2003). An empirical investigation of KM styles and their effect on corporate performance. Information \& Management, 40(5), 403-417. https://doi.org/10.1016/S0378-7206(02)00060-5

Clemons, E. K., \& Row, M. C. (1991). Sustaining IT advantage: The role of structural differences. MIS Quarterly, 15(3), 341-352. https://doi.org/10.2307/249639

Cohen, W. M., \& Levinthal, D. A. (1990). Absorptive capacity: A new perspective on learning and innovation. Administrative Science Quarterly, 35(1), 128-135. https://doi.org/10.1002/kpm.143

Conner, K. R. (1991). A historical comparison of the Resource-Based Theory and five schools of thought within Industrial Organization Economics: Do we have a new theory of the firm. Journal of Management, 17(1), 121-154. https://doi.org/10.1177/014920639101700109

Conner, K. R., \& Prahalad, C. K. (1996). A Resource-based Theory of the firm: Knowledge versus opportunism. Organization Science, 7(5), 477-501. https://doi.org/10.1287/orsc.7.5.477

Croteau, A. M., \& Raymond, L. (2004). Performance outcomes of strategic and IT competencies alignment. Journal of Information Technology, 19(3), 178-190. https://doi.org/10.1057/palgrave.jit.2000020

Das, S. R., Zahra, S. A., \& Warkentin, M. E. (1991). Integrating the content and process of strategic MIS planning with competitive strategy. Decision Sciences, 22(5), 953-984. https://doi.org/10.1111/j.1540-5915.1991.tb01902.x

Davenport, T. H., Jarvenpaa, S. L., \& Beers, M. C. (1996). Improving knowledge work processes. Sloan Management Review, 37(4), 53-65.

Davenport, T. H., \& Prusak, L. (1998). Working knowledge: How organizations manage what they know. Massachusetts: Harvard Business School Press, Boston.

Dess, G. G., \& Robinson, R. B. (1984). Measuring organizational performance in the absence of objective measures: The case of the privately-held firm and conglomerate business unit. Strategic Management Journal, 5(3), 265-273. https://doi.org/10.1002/smj.4250050306

Drucker, P. F. (1993). Post-Capitalist Society. HarperCollins Publishers, New York.

Dulipovici, A., \& Robey, D. (2013). Strategic alignment and misalignment of knowledge management systems: A social representation perspective. Journal of Management Information Systems, 29(4), 103-126. https://doi.org/10.2753/MIS0742-1222290404

Earl, M. J. (1989). Management Strategies for Information Technology. Prentice Hall, New York.

Earl, M. J. (2001). Knowledge management strategies: Toward a taxonomy. Journal of Management Information Systems, 18(1), 215-233. https://doi.org/10.1080/07421222.2001.11045670

Fehér, P. (2002). The missing link in the integration of knowledge management practices and technology solutions. European Conference on Information Systems, Gdansk, Poland, 939-950.

Fornell, C., \& Larcker, D. E. (1981). Evaluating structural equation models with unobservable and measurement error. Journal of Marketing Research, 18(1), 39-50. https://doi.org/10.1177/002224378101800104

Garavelli, C., Gorgoglione, M., \& Scozzi, B. (2004). Knowledge management strategy and organization: A perspective of analysis. Knowledge and Process Management, 11(4), 273-282. https://doi.org/10.1002/kpm.209

Gold, A. H., Malhotra, A., \& Segars, A. H. (2001). Knowledge management: An organizational capabilities perspective. Journal of Management Information Systems, 18(1), 185-214. https://doi.org/10.1080/07421222.2001.11045669

Grant, R. M. (1996). Prospering in dynamically competitive environments: Organizational capability as knowledge integration. Organizational Science, 7(4), 375-387. https://doi.org/10.1287/orsc.7.4.375

Grover, V. G., \& Davenport, T. H. (2001). General perspectives on knowledge management: Fostering a research agenda. Journal of Management Information Systems, 18(1), 5-21. https://doi.org/10.1080/07421222.2001.11045672 
Hair, J. F., Black, W. C., Babin, B. J., Anderson, R. E., \& Tatham, R. L. (2006). Multivariate Data Analysis. Pearson Education Inc., Upper Saddle River, New Jersey.

Hansen, M. T., Nohria, N., \& Tierney, T. (1999). What's your strategy for managing knowledge? The knowledge management yearbook 2000-2001, 77(2), 106-116.

Henderson, J. C., \& Venkatraman, N. (1993). Strategic alignment: Leveraging information technology for transforming organizations. IBM Systems Journal, 32(1), 4-16. https://doi.org/10.1147/SJ.1999.5387096

Iqbal, A., Latif, F., Marimon, F., \& Sahibzada, U. F. (2018). From knowledge management to organizational performance: Modelling the mediating role of innovation and intellectual capital in higher education. Journal of Enterprise Information Management. https://doi.org/10.1108/JEIM-04-2018-0083

Johannessen, J., \& Olsen, B. (2003). Knowledge management and sustainable competitive advantages: The impact of dynamic contextual training. International Journal of Information Management, 23(4), 277-289. https://doi.org/10.1016/S0268-4012(03)00050-1

Kankanhalli, A., Tanudidjaja, F., Sutanto, J., \& Tan B. C. Y. (2003). The role of IT in successful knowledge management initiatives. Communications of the ACM, 46(9), 69-73. https://doi.org/10.1145/903893.903896

Khandwalla, P. N. (1977). The Design of Organizations. Harcourt Brace Jovanovich, New York.

Kim, S. K. (2001). An empirical study of the relationship between knowledge management and information technology infrastructure capability in the management consulting industry. Unpublished doctoral dissertation, University of Nebraska.

Kogut, B., \& Zander, U. (1992). Knowledge of the firm, combinative capabilities, and the replication of technology. Organization Science, 3(3), 383-397. https://doi.org/10.1287/orsc.3.3.383

Lee, H., \& Choi, B. (2003). Knowledge management enablers, process, and organizational performance: An integrative view and empirical examination. Journal of Management Information Systems, 20(1), 179-228. https://doi.org/10.1080/07421222.2003.11045756

Lee, K. C., Lee, S., \& Kang, I. W. (2005). KMPI: Measuring knowledge management performance. Information \& Management, 42(3), 469-482. https://doi.org/10.1016/j.im.2004.02.003

Mahapatra, R. K., \& Sarkar, S. (2000). The role of information technology in knowledge management. Proceedings of the American Conference on Information Systems (pp. 1288-1290). Long Beach, California.

Markus, M. L., \& Soh, C. (1993). Banking on Information Technology: Converting IT Spending into Firm Performance. In R. D. Banker, R. J. Kauffman, \& M. A. Mahmood (Eds.), Perspectives on the Strategic and Economic Value of Information Technology Investment (pp. 364-392). Ideal Group Publishing.

Marques, C. S., Marques, C. P., Leal, C. T., \& Cardoso, A. R. (2017). Knowledge, innovation, internationalisation and performance: Insights from the Portuguese footwear industry. International Journal of Entrepreneurship and Small Business, 32(3), 299-313. https://doi.org/10.1504/IJESB.2017.087026

Nonaka, I., \& Konno, N. (1998). The concept of "ba": Building a foundation of knowledge creation. California Management Review, 40(3), 40-54. https://doi.org/10.2307/41165942

Ostroff, C., \& Schmitt, N. (1993). Configurations of organizational effectiveness and efficiency. Academy of Management Journal, 36(6), 1345-1361. https://doi.org/10.5465/256814

Polanyi, M. (1997). The Tacit Dimension. In L. Prusak (Ed.), Knowledge in Organizations (pp. 135-146). Butterworth- Heinemann, Boston.

Quinn, J. B., \& Baily, M. (1994). Information technology: Increasing productivity in services. Academy of Management Perspectives, 8(3), 28-48. https://doi.org/10.5465/ame.1994.9503101167

Robertson, J. (2004). Developing a knowledge management strategy. KM Column. Retrieved July 10, 2011, from http://www.steptwo.com.au/papers/kmc_kmstrategy/index.html

Ruggles, R. (1998). The state of the notion: Knowledge management in practice. California Management Review, 40(3), 80-89. https://doi.org/10.2307/41165944

Sabherwal, R., \& Grant, J. H. (1994). Integrating External and Internal Perspectives of Strategic Information Technology Decisions. In N. Venkatraman, \& J. Henderson (Eds.), Research in Strategic Management and Information Technology. JAI Press, England.

Scheepers, R., Venkitachalam, K., \& Gibbs, M. R. (2004). Knowledge strategy in organizations: Refining the 
model of Hansen, Nohria \& Tierney. Journal of Strategic Information Systems, 13(3), 201-222. https://doi.org/10.1016/j.jsis.2004.08.003

Schulze, W. S. (1992). The two Resource-Based Models of the firm: Definitions and implications for research. Proceedings of Academy of Management (pp. 37-41). Briarcliff Manor, NY: Academy of Management.

Schultze, U., \& Leidner, D. E. (2002). Studying knowledge management in information systems research: Discourses and theoretical assumptions. MIS Quarterly, 26(3), 213-242. https://doi.org/10.2307/4132331

Scott, J. E. (1998). Organizational knowledge and the Intranet. Decision Support Systems, 23(1), 3-17. https://doi.org/10.1016/S0167-9236(98)00032-3

Sher, P. J., \& Lee, V. C. (2004). Information technology as a facilitator for enhancing dynamic capabilities through knowledge management. Information \& Management, 41(8), 933-945. https://doi.org/10.1016/j.im.2003.06.004

Shih, H. A., \& Chiang, Y. H. (2005). Strategy alignment between HRM, KM and corporate development. International Journal of Manpower, 26(6), 582-602. https://doi.org/10.1108/01437720510625476

Singh, M. (2000). Toward a Knowledge Management View of Electronic Business: Introduction and Investigation of the Knowledge Chain Model for Competitive Advantage (Unpublished Dissertation). University of Kentucky, Lexington, Kentucky.

Tanriverdi, H. (2005). Information technology relatedness, knowledge management capability, and performance of multibusiness firms. MIS Quarterly, 29(2), 311-334. https://doi.org/10.2307/25148681

Tippins, M. J., \& Sohi, R. S. (2003). IT competency and firm performance: Is organizational learning a missing link? Strategic Management Journal, 24(8), 745-761. https://doi.org/10.1002/smj.337

Tiwana, A. (2012). Novelty-knowledge alignment: A theory of design convergence in systems development. Journal of Management Information Systems, 29(1), 15-52. https://doi.org/10.2753/MIS0742-1222290101

Venkatraman, N., \& Ramanujam, V. (1986). Measurement of business performance in strategy research: A comparison of approached. Academy of Management Review, 11(4), 801-814. https://doi.org/10.5465/amr.1986.4283976

Venkatraman, N. (1989). Strategic orientation of business enterprises: The construct, dimensionality, and measurement. Management Science, 35(8), 942-962. https://doi.org/10.1287/mnsc.35.8.942

Wakefield, R. L. (2005). Identifying knowledge agents in a KM strategy: The use of the structural influence index. Information \& Management, 42(7), 935-945. https://doi.org/10.1016/j.im.2004.10.002

Wiig, K. M. (1995). Knowledge Management Methods: Practical Approach to Managing Knowledge. Schema Press, TX.

Wu, P. J., Straub, D. W., \& Liang, T. P. (2015). How information technology governance mechanisms and strategic alignment influence organizational performance: Insights from a matched survey of business and IT managers. MIS Quarterly, 39(2), 497-518. https://doi.org/10.25300/MISQ/2015/39.2.10

Yu, S. H., Kim, Y. G., \& Kim, M. Y. (2004). Linking organizational knowledge management drivers to knowledge management performance: An exploratory study. Proceedings of the 37th Hawaii International Conference on System Sciences.

Zack, M. H. (1999a). Developing a knowledge strategy. California Management Review, 41(3), 125-145. https://doi.org/10.2307/41166000

Zack, M. H. (1999b). Managing codified knowledge. Sloan Management Review, 40(4), 45-58.

Zack, M. H. (2002). Epilogue: Developing a Knowledge Strategy, In C.W. Choo, \& Bontis (Ed.), The Strategic Management of Intellectual Capital and Organizational Knowledge (pp. 268-276). Oxford: Oxford University Press.

\section{Copyrights}

Copyright for this article is retained by the author(s), with first publication rights granted to the journal.

This is an open-access article distributed under the terms and conditions of the Creative Commons Attribution license (http://creativecommons.org/licenses/by/4.0/). 